\title{
Length of pseudopregnancy and pattern of uterine protein release as influenced by time and duration of oestrogen administration in the pig
}

\author{
R. D. Geisert, M. T. Zavy*, R. P. Wettemann and B. G. Biggers \\ Animal Science Department, Oklahoma Agricultural Experiment Station, Stillwater, Oklahoma \\ 74078, U.S.A. and ${ }^{*}$ US Department of Agriculture, ARS, El Reno, Oklahoma 73036, U.S.A.
}

\begin{abstract}
Summary. Treatment of gilts with $5 \mathrm{mg}$ oestradiol benzoate on Day $9 \cdot 5,11,12 \cdot 5,14,15 \cdot 5$ or Days 14-16 resulted in an interoestrous interval of about 30 days. Administration of oestradiol benzoate daily from Days 11 to 15 or two periods of treatment on Days 11 and 14 to 16 resulted in prolonging $C L$ function beyond 60 days from the pre-treatment oestrus. Endometrial secretory response to oestrogen stimulation, based on the ability of oestrogen to release calcium and uterine protein into the lumen appears to occur after Day 10 of the oestrous cycle.

The results suggest that maintenance of prolonged CL function appears to require two periods of oestrogen stimulation. The first period occurs on Day 11 when the endometrium has become responsive to oestrogen stimulation followed by a second prolonged increase in oestrogen stimulation after Day 14. These findings accord with the normal patterns of oestrogen released by pig blastocysts during early pregnancy.
\end{abstract}

\section{Introduction}

In the pig, establishment of pregnancy begins about 11-12 days after the start of oestrus (Dhindsa \& Dziuk, 1968). The ability of the blastocyst to synthesize and release oestrogen during this period (Perry et al., 1973; Gadsby et al., 1980; Geisert et al., 1982b) is presumed to be the 'maternal recognition' signal which results in extended luteal function (see Bazer et al., 1984 for review).

Exogenous oestrogen administration between Days 11 and 15 of the oestrous cycle prolongs luteal function (pseudopregnancy) in the pig (Gardner et al., 1963; Frank et al., 1977; Saunders et al., 1983). In gilts, daily administration of $5 \mathrm{mg}$ oestradiol valerate from Days 11 through 15 of the oestrous cycle extends the interoestrous interval to more than 50 days (Frank et al., 1977). Geisert et al. (1982c) indicated that a single $5 \mathrm{mg}$ i.m. injection of oestradiol valerate on Day 11 of the oestrous cycle produced an increase in uterine luminal content of calcium, protein and acid phosphatase activity similar to that obtained after oestrogen release by elongating blastocysts during early pregnancy (Geisert et al., 1982a, b). Although a single oestrogen injection appeared to mimic the uterine response which occurs on Days 11-12 of pregnancy, the effect on inducing prolonged luteal function has not been clearly determined.

Blastocysts must reach the developmental stage at which they are able to synthesize the oestrogen (Geisert et al., 1982b) that stimulates the uterine endometrium and prevents CL regression. Concurrently, the endometrium has to reach a developmental stage which is responsive to oestrogen release by the elongating blastocyst. Previous studies have indicated that oestrogen administration before Day 10 and after Day 16 failed to induce prolonged CL function in gilts (Kidder et al., 1955; Gardner et al., 1963). In addition, low doses of oestrogen given either subcutaneously or through intrauterine infusion from Day 10 to 14 of the oestrous cycle failed to extend CL function beyond Day 24 (Saunders et al., 1983). These studies suggest that the uterine endometrium may not only be 
responsive to oestrogen during discrete periods of the oestrous cycle, but the magnitude of stimulation may also play an important role in CL maintenance.

The following study was carried out to establish (1) the time and duration of exogenous oestrogen administration needed to induce prolonged luteal function in the gilt and (2) the period of the oestrous cycle at which the uterine endometrium can be stimulated to release calcium and protein (quantitative and qualitative) into the uterine lumen in response to oestrogen treatment.

\section{Materials and Methods}

Experiment 1 . Thirty-two (32) sexually mature (100-118 kg), cyclic Yorkshire gilts were utilized to determinate the day(s) of the oestrous cycle in which administration of exogenous oestradiol benzoate would induce prolonged luteal function. Gilts were randomly assigned (4/group) to receive one of the following treatments: control, intramuscular injection $(4 \mathrm{ml})$ of vehicle (sesame oil) on Days 11 through 15 of the oestrous cycle (Day $0=$ first day of oestrus); a $5 \mathrm{mg}$ intramuscular injection of oestradiol benzoate (17 $\beta$-oestradiol 3-benzoate; Sigma Chemical Company, St Louis, MO, U.S.A.) on Days 11 through 15; Days 11 and 15; and on Days 9.5, 11.0, 12.5, 14 or 15.5 of the oestrous cycle. All gilts were observed for oestrous activity twice daily with an intact boar. Blood samples were collected from the jugular vein every 3rd day from Days 16 to 31 by venepuncture. Samples were immediately placed on ice, centrifuged to obtain plasma and stored at $-20^{\circ} \mathrm{C}$ until assayed for progesterone concentration.

Gilts which did not express oestrus within 60 days after the pre-treatment oestrus were laparotomized to determine whether CL function had been maintained by oestrogen treatment. Prolonged luteal function was confirmed by the presence of CL and the accumulation of large quantities of particulate material in the uterine lumen (Basha et al., 1980).

Experiment 2. Twenty-eight (28) cyclic crossbred gilts were used to study the influence of oestrogen administration during two periods of the oestrous cycle. Gilts (4/group) were randomly assigned to receive control treatment, i.e. vehicle $(4 \mathrm{ml}$, i.m.) administered on Days 11 through 15 of the oestrous cycle, or oestradiol benzoate $(5 \mathrm{mg}, \mathrm{i} . \mathrm{m}$.) administered on Days 11, 14, 11 and 15,14-16, 11 and 14-16 or Days 11 and 20-22. Gilts were checked for oestrous activity daily with intact boars. Animals which did not express overt oestrous behaviour by Day 60 were laparotomized to confirm that prolonged luteal function had occurred as previously described in Exp. 1 .

Experiment 3. Twenty-four (24) cyclic crossbred gilts were used to investigate the effect of exogenous oestrogen on uterine secretion of calcium, protein, prostaglandin $F$, and acid phosphatase activity $12 \mathrm{~h}$ after injection during different days of the oestrous cycle. Gilts (4/group) were randomly assigned to be hemi-hysterectomized on Days $9 \cdot 5,11 \cdot 5$ or 14 of the oestrous cycle. Anaesthesia was induced with a 5\% solution of thiopentone sodium (Abbott Laboratories, Chicago, IL, U.S.A.) administered intravenously and maintained on a closed-system gas anaesthetic machine with halothane (Fluothane: Aveco Co., Inc., Fort Dodge, IA, U.S.A.).

After midventral laparotomy, one uterine horn and the ipsilateral ovary were removed and placed on ice. Immediately after surgery, gilts were randomly treated with vehicle $(4 \mathrm{ml}$, i.m.) or oestradiol benzoate $(5 \mathrm{mg}$, i.m.). The remaining uterine horn was then removed $12 \mathrm{~h}$ after treatment injection.

The uterine horn was trimmed free of mesometrium and flushed with $20 \mathrm{ml}$ sterile saline $(9 \mathrm{~g} \mathrm{NaCl} / \mathrm{l})$ to recover uterine luminal contents within $10 \mathrm{~min}$ of removal. The uterine flushings were placed in tubes on ice until centrifuged at $12000 \mathrm{~g}$ for $20 \mathrm{~min}$ at $4^{\circ} \mathrm{C}$. The supernatant was stored at $-20^{\circ} \mathrm{C}$ until analysed for calcium, prostaglandin $\mathrm{F}$, acid phosphatase activity, and quantitative and qualitative protein changes.

Experiment 4. Eight (8) cyclic crossbred gilts were used to determine whether the extended luteal function in gilts treated with a pharmacological dose of oestrogen on Day 9.5 of the oestrous cycle (Exp. la) resulted from a carry-over of oestrogen to Day 11 of the cycle. Gilts (4/group) were randomly assigned to receive an i.m. injection of vehicle $(4 \mathrm{ml})$ or oestradiol benzoate $(5 \mathrm{mg})$ on Day 9.5 of the oestrous cycle. Animals were hemi-hysterectomized on Day I1, followed by removal of the second uterine horn on Day 12. Uterine horns were immediately placed on ice and flushed as described in Exp. 3. Uterine flushings were analysed for calcium, acid phosphatase activity, and for qualitative and quantitative protein changes.

Hormone radioimmunoassay. Plasma progesterone concentrations were quantified in duplicate by radioimmunoassay as previously described (Hallford et al., 1975). The sensitivity of the assay by this procedure was $0 \cdot 1 \mathrm{ng} / \mathrm{ml}$. Intra- and inter-assay coefficients of variation were $10 \cdot 6 \%$ and $8.6 \%$, respectively.

Prostaglandin concentrations in uterine flushings were measured by a double-antibody radioimmunoassay using the procedures previously described by Geisert et al. (1986). The PGF-2 $\alpha$ antiserum (gift from Dr K. T. Kirton, Upjohn Company, Kalamazoo, MI, U.S.A.) cross-reacted <0.1\% with PGA, PGA-2, PGB, PGB-2, PGE-2, PGE-3; $<1 \%$ for 15 -keto PGF- $2 \alpha$ and $8 \%$ for PGF- $1 \alpha$ (Cornette et al., 1972). Therefore, data are expressed as immunoreactive PGF. Sensitivity of the assay with respect to the standard curve was $25 \mathrm{pg}$. All samples were measured in a single assay which had an intraassay coefficient of variation of $5 \%$.

Uterine calcium analysis. Calcium concentrations in uterine flushings were measured with a Calcette calcium analyser (Precision Systems, Inc., Sudbury, MA, U.S.A.). The system utilized ethylene glycoltetraacetic acid for fluorometric titration of calcium in aqueous solutions (Alexander, 1971). 
Uterine protein and acid phosphatase activity. Protein concentration in uterine flushings was determined by the method of Lowry et al. (1951). Acid phosphatase activity was determined, using $p$-nitrophenyl-phosphate as the substrate as previously described by Basha et al. (1979). One unit of activity was defined as the capacity to release $1 \mu \mathrm{mol} p$-nitrophenol per min at $\mathrm{pH} 4.9$ in $0.1 \mathrm{M}$-acetate buffer.

Two-dimensional polyacrylamide gel electrophoresis (PAGE). Qualitative changes in protein collected in uterine flushings were analysed by 2-dimensional PAGE. Uterine flushings ( $2 \mathrm{mg}$ protein) were dialysed (molecular weight cut-off $\cong 3500$ ) against several volumes of $1 \mathrm{~mm}$-Tris- $\mathrm{HCl}$ buffer ( $\mathrm{pH} \mathrm{8.2)}$. After lyophilization, the dialysed uterine protein was prepared for PAGE by being directly dissolved in $1 \mathrm{ml} 5 \mathrm{mM}-\mathrm{K}_{2} \mathrm{CO}_{3}$ containing $9 \cdot 4 \mathrm{M}-\mathrm{urea}, 2 \%(\mathrm{v} / \mathrm{v}$ ) Nonidet P-40 and $0.5 \%(\mathrm{w} / \mathrm{v})$ dithiothreitol. The PAGE was performed ( $300 \mu \mathrm{g}$ protein loaded) for acidic and basic proteins according to the method described by Basha et al. (1979).

Statistical analyses. Data were analysed by least squares analyses of variance using the General Linear Models procedures of the Statistical Analysis System (Barr et al., 1979). Comparison of average interoestrous interval among treatments in Exp. 1 and 2 was made by orthogonal contrasts. Plasma progesterone concentrations between treatments were analysed by split-plot analysis for repeated measurements (Gill \& Hafs, 1971). The overall statistical model for analyses of uterine flushings in Exp. 3 included effects of treatment, pig (treatment), and horn and treatment by horn interactions. Although treatments were not assigned until after removal of the first uterine horn, horn was included in the statistical model rather than using within animal differences so that changes across time (first versus second horn) could be analysed. Treatment by horn interaction was used as the appropriate term to evaluate effects of oestrogen on uterine secretion. Orthogonal contrasts of treatment by horn interactions were vehicle $v s$ oestradiol benzoate on Days 9.5,11.5 and 14. The overall statistical model for Exp. 4 included effects of treatment, pig (treatment), day and treatment by day interactions.

\section{Results}

\section{Experiment 1}

Interoestrous intervals for oestradiol benzoate and vehicle treated gilts are summarized in Table 1 and the profiles for the plasma progesterone concentrations from each treatment group are given in Fig. 1. Gilts treated with oestradiol benzoate on Days $9.5,11,12.5$ or 14 had average oestrous cycle lengths of about 29 days. One of 4 gilts treated with oestradiol benzoate on Day 14 and 2 of 4 gilts treated on Day 15.5 exhibited cycles (18 days) which were not extended, whereas the remaining

Table 1. Interoestrous intervals in vehicle- and oestradiol benzoate (EB)-treated gilts in Exps 1 and 2

\begin{tabular}{ccccc}
\hline Exp. & Treatment & $\begin{array}{c}\text { Day of } \\
\text { treatment }\end{array}$ & $\begin{array}{c}\text { Days } \dagger \\
\text { (mean } \pm \text { s.e.m.) }\end{array}$ & $\begin{array}{c}\text { Gilts with } \\
\text { interval } \\
>35 \text { days }\end{array}$ \\
\hline 1 & Vehicle & $11-15$ & $18 \cdot 8 \pm 0 \cdot 2^{\mathrm{a}}$ & $0 / 4$ \\
& EB & $9 \cdot 5$ & $28 \cdot 0 \pm 0 \cdot 6^{\text {bc }}$ & $0 / 4$ \\
& $11 \cdot 0$ & $29 \cdot 0 \pm 1 \cdot 5^{\text {bc }}$ & $0 / 4$ \\
& $12 \cdot 5$ & $28 \cdot 8 \pm 1 \cdot 1^{\text {bc }}$ & $0 / 4$ \\
& $14 \cdot 0$ & $26 \cdot 5 \pm 2 \cdot 9^{\text {bd }}$ & $0 / 4$ \\
& & $15 \cdot 5$ & $23 \cdot 5 \pm 3 \cdot 2^{\text {d }}$ & $0 / 4$ \\
& & $11+15$ & $30 \cdot 5 \pm 1 \cdot 7^{\text {bc }}$ & $0 / 4$ \\
& $11-15$ & $>60^{\mathrm{e}}$ & $4 / 4$ \\
\hline 2 & Vehicle & $11-15$ & $19 \cdot 7 \pm 0 \cdot 1^{\mathrm{a}}$ & $0 / 4$ \\
& EB & $11 \cdot 0$ & $28 \cdot 7 \pm 1 \cdot 1^{\mathrm{b}}$ & $0 / 4$ \\
& $14 \cdot 0$ & $29 \cdot 7 \pm 0 \cdot 5^{\mathrm{b}}$ & $0 / 4$ \\
& 11,14 & $32 \cdot 2 \pm 1 \cdot 0^{\mathrm{b}}$ & $0 / 4$ \\
& $14-16$ & $31 \cdot 0 \pm 10^{\mathrm{b}}$ & $1 / 4$ \\
& & & $>60^{\mathrm{c}}$ & $4 / 4$ \\
& & 11 and $14-16$ & $40 \cdot 5 \pm 11 \cdot 3^{\mathrm{b}}$ & $2 / 4$ \\
\hline
\end{tabular}

* $5 \mathrm{mg}$ oestradiol benzoate given i.m. in $250 \mu \mathrm{l}$ vehicle.

$\dagger$ Differences in treatment means were evaluated by orthogonal comparisons; values with different superscripts are different $(P<0.02)$. 


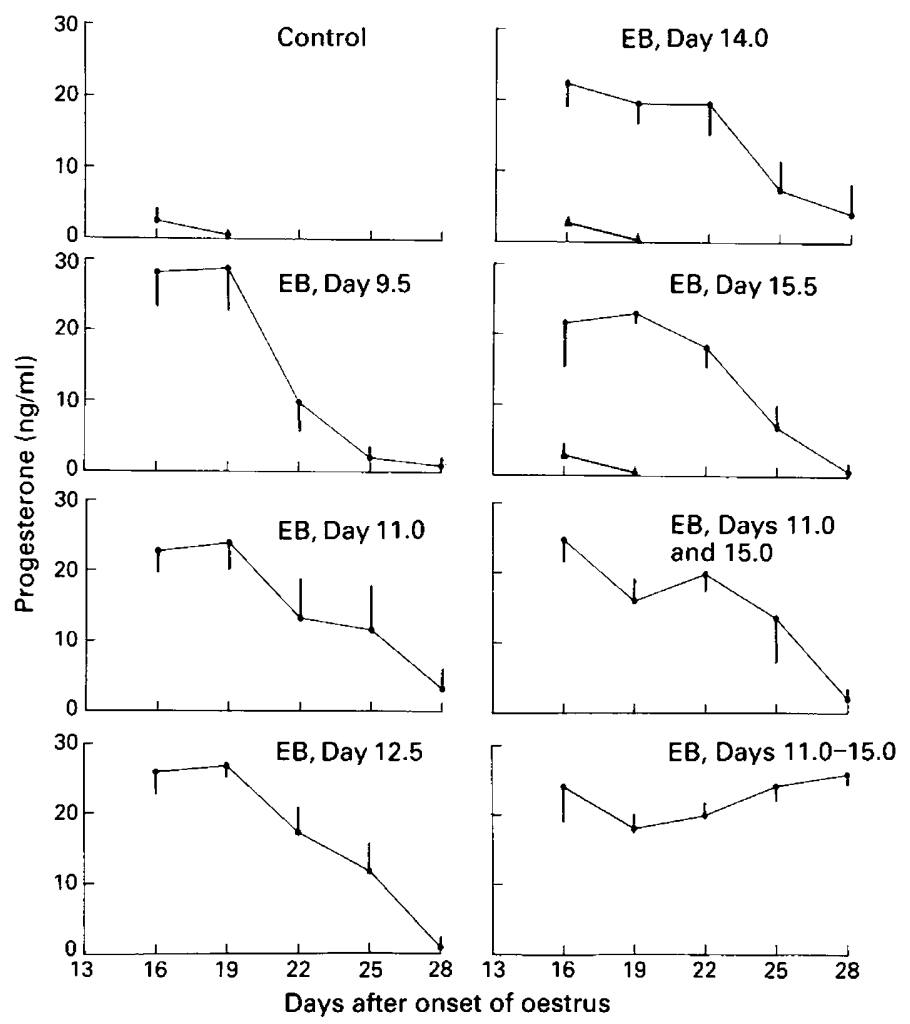

Fig. 1. Plasma progesterone concentrations $(\bullet)$ of gilts treated with $5 \mathrm{mg}$ oestradiol benzoate (EB) or vehicle (control) on different days of the oestrous cycle. $\boldsymbol{\Delta}$, Represents progesterone concentrations of gilts that did not exhibit an extended oestrous cycle length after EB treatment on Days 14 and 15.5.

gilts in these two groups averaged 29 days. All gilts receiving oestradiol benzoate daily from Day 11 through 15 failed to exhibit oestrus during the 60 days from the pre-treatment oestrus $(P<0.001)$.

Evaluation of plasma progesterone profiles of gilts which responded to treatment indicated that oestradiol benzoate extended luteal function $(P<0.01)$ for 8 to 10 days compared with vehicletreated controls (Fig. 1). With the exception of gilts treated with oestradiol benzoate from Days 11 through 15, plasma progesterone concentrations of gilts with an extended interoestrous interval remained elevated on Days 19-22 followed by a decline on Days 25-28.

Laparotomy performed on gilts which failed to exhibit oestrus by Day 60 revealed the presence of large functional CL on the ovaries, with the uterus appearing large and flaccid. Centrifugation of uterine flushings removed the large quantities of particulate material which were present in the uterine lumen, leaving the supernatant a bright purple colour indicative of gilts which have had CL function extended for 60 days (Basha et al., 1980).

\section{Experiment 2}

As was observed in Exp. 1, oestradiol benzoate extended the oestrous cycle length $(P<0 \cdot 01)$ compared with vehicle-treated controls (Table 1). Gilts treated on Days 11, 14 or 11 and 14 of the oestrous cycle returned to oestrus $\sim 30$ days after the pre-treatment oestrus. Treatment of gilts from Days 14 to 16 produced three different responses. Two gilts exhibited oestrous cycle lengths 
which were slightly shortened (16-17 days) compared to controls, 1 gilt had an oestrous cycle length of 31 days and the remaining gilt had maintained luteal function as indicated at laparotomy on Day 60. Similar variation occurred when gilts were treated on Days 11 and 20-22, with the 4 gilts exhibiting oestrous cycle lengths of 19,23,60 and 60 days, respectively. Only treatment of gilts with oestradiol benzoate on Days 11 and 14-16 extended luteal function for $>60$ days in all animals $(P<0.01)$.

\section{Experiment 3}

Total uterine luminal content of calcium, protein, acid phosphatase activity and PGF in uterine flushings from vehicle and oestradiol benzoate treated gilts are presented in Table 2. Uterine calcium content was increased $(P<0.01) 12 \mathrm{~h}$ after oestradiol benzoate treatment on Day 11.5 $(P<0.01)$ and Day $14(P<0.05)$, but was not influenced by treatment on Day $9 \cdot 5$. Although uterine luminal protein content tended to increase after treatment on all days, only the increase on Day 14 was significant $(P<0.04)$. Administration of oestradiol benzoate on Day 11.5 increased $(P<0.05)$ acid phosphatase activity in the uterine flushings to amounts comparable to that measured on Day 14 in control gilts. Acid phosphatase activity was greatest on Day 14, but was not significantly affected by oestradiol benzoate. Prostaglandin F content in uterine flushings did not change as a result of treatment or day of the oestrous cycle, but calcium, protein and acid phosphatase activity increased $(P<0.01)$ across the days of the oestrous cycle.

Profiles of acidic polypeptides present in the uterine flushing from a vehicle- and an oestradiol benzoate-treated gilt are illustrated in Fig. 2. Serum albumin was the major protein present in all flushings along with the appearance of two additional non-serum proteins $\left(M_{\mathrm{r}} \cong 18000, \mathrm{pH} 6 \cdot 6-6 \cdot 3\right)$ on Days 12 and 14.5 of the oestrous cycle (Fig. $2 \mathrm{~b}$ and $2 \mathrm{c}$ ). These two acidic polypeptides were not detectable in gels from vehicle- or oestradiol benzoate-treated gilts on Day 10 (Fig. $2 \mathrm{a}$ ).

Basic polypeptides isolated by PAGE which were detected in uterine flushings of oestradioland vehicle-treated gilts are presented in Fig. 3. Uteroferrin $\left(M_{\mathrm{r}} \cong 35000 ; \mathrm{pH}=7 \cdot 2\right)$ is indicated

Table 2. Total calcium, protein, acid phosphatase activity and prostaglandin $F$ in uterine flushings from vehicle- and oestradiol benzoate-treated gilts (Exp. 3)*

\begin{tabular}{|c|c|c|c|c|c|}
\hline \multirow[b]{3}{*}{ Day } & & \multicolumn{4}{|c|}{ Treatment } \\
\hline & & \multicolumn{2}{|c|}{ Vehicle } & \multicolumn{2}{|c|}{ Oestradiol benzoate } \\
\hline & & First horn & Second horn & First horn & Second horn \\
\hline $9 \cdot 5$ & $\begin{array}{l}\text { Calcium (mg) } \\
\text { Protein (mg) } \\
\text { Acid phosphatase activity } \dagger \\
\text { PGF (ng) }\end{array}$ & $\begin{array}{c}\text { ND } \\
20 \cdot 8 \\
4 \cdot 4 \\
0 \cdot 74\end{array}$ & $\begin{array}{c}\text { ND } \\
24 \cdot 8 \\
5 \cdot 5 \\
0 \cdot 60\end{array}$ & $\begin{array}{c}0 \cdot 01 \\
33 \cdot 1 \\
5 \cdot 3 \\
0 \cdot 59\end{array}$ & $\begin{array}{c}0.02 \\
45 \cdot 2 \\
7 \cdot 0 \\
1 \cdot 79\end{array}$ \\
\hline $11 \cdot 5$ & $\begin{array}{l}\text { Calcium }^{\mathbf{a}} \\
\text { Protein } \\
\text { Acid phosphatase activity } \\
\text { PGF }\end{array}$ & $\begin{array}{c}0 \cdot 11 \\
18 \cdot 5 \\
4 \cdot 6 \\
0.83\end{array}$ & $\begin{array}{l}0 \cdot 15 \\
17 \cdot 8 \\
10 \cdot 7 \\
1 \cdot 36\end{array}$ & $\begin{array}{c}0 \cdot 27 \\
18 \cdot 1 \\
4 \cdot 2 \\
1 \cdot 01\end{array}$ & $\begin{array}{c}1 \cdot 85 \\
27 \cdot 5 \\
34 \cdot 9 \\
2 \cdot 57\end{array}$ \\
\hline 14 & $\begin{array}{l}\text { Calcium }{ }^{\mathrm{b}} \\
\text { Protein } \\
\text { Acid phosphatase activity } \\
\text { PGF }\end{array}$ & $\begin{array}{c}0 \cdot 40 \\
46 \cdot 7 \\
38 \cdot 9 \\
7 \cdot 00\end{array}$ & $\begin{array}{l}0.33 \\
47 \cdot 0 \\
56 \cdot 5 \\
1.68\end{array}$ & $\begin{array}{c}0 \cdot 39 \\
25 \cdot 4 \\
22 \cdot 8 \\
3 \cdot 12\end{array}$ & $\begin{array}{l}1 \cdot 61 \\
42 \cdot 7 \\
75 \cdot 6 \\
1.80\end{array}$ \\
\hline
\end{tabular}

*Overall s.e.m. was $\pm 0 \cdot 25$ for calcium, $\pm 3 \cdot 3$ for protein, $\pm 5 \cdot 6$ for acid phosphatase activity and \pm 0.92 for PGF.

$\dagger \mu \mathrm{mol} \mathrm{P}_{\mathrm{i}}$ released/min using $p$-nitrophenyl phosphate as substrate at $30^{\circ} \mathrm{C}$.

${ }^{a}$ Treatment $\times$ horn interaction $(P<0 \cdot 01)$.

${ }^{b}$ Treatment $x$ horn interaction $(P<0.05)$.

ND $=$ Nondetectable. 


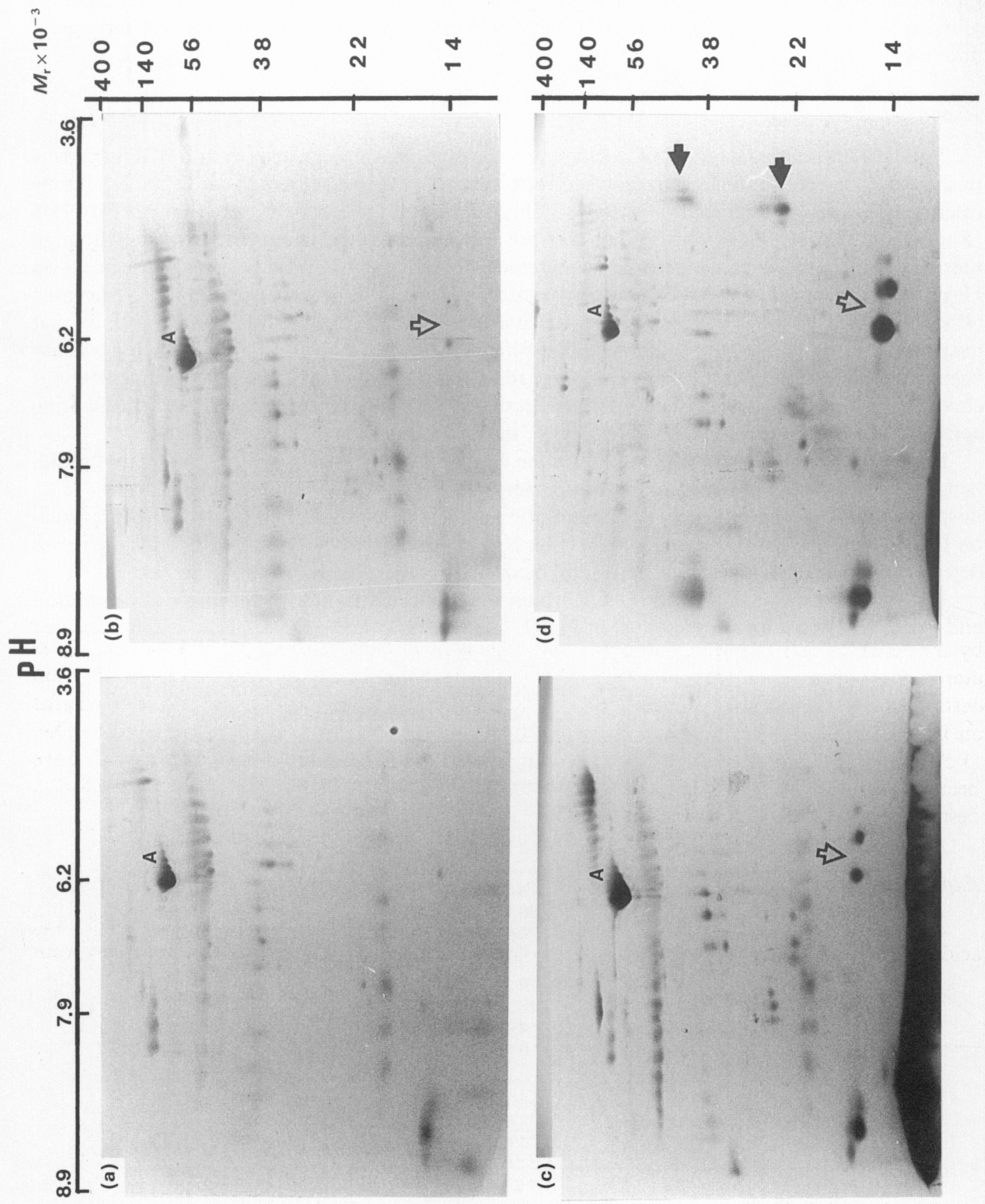




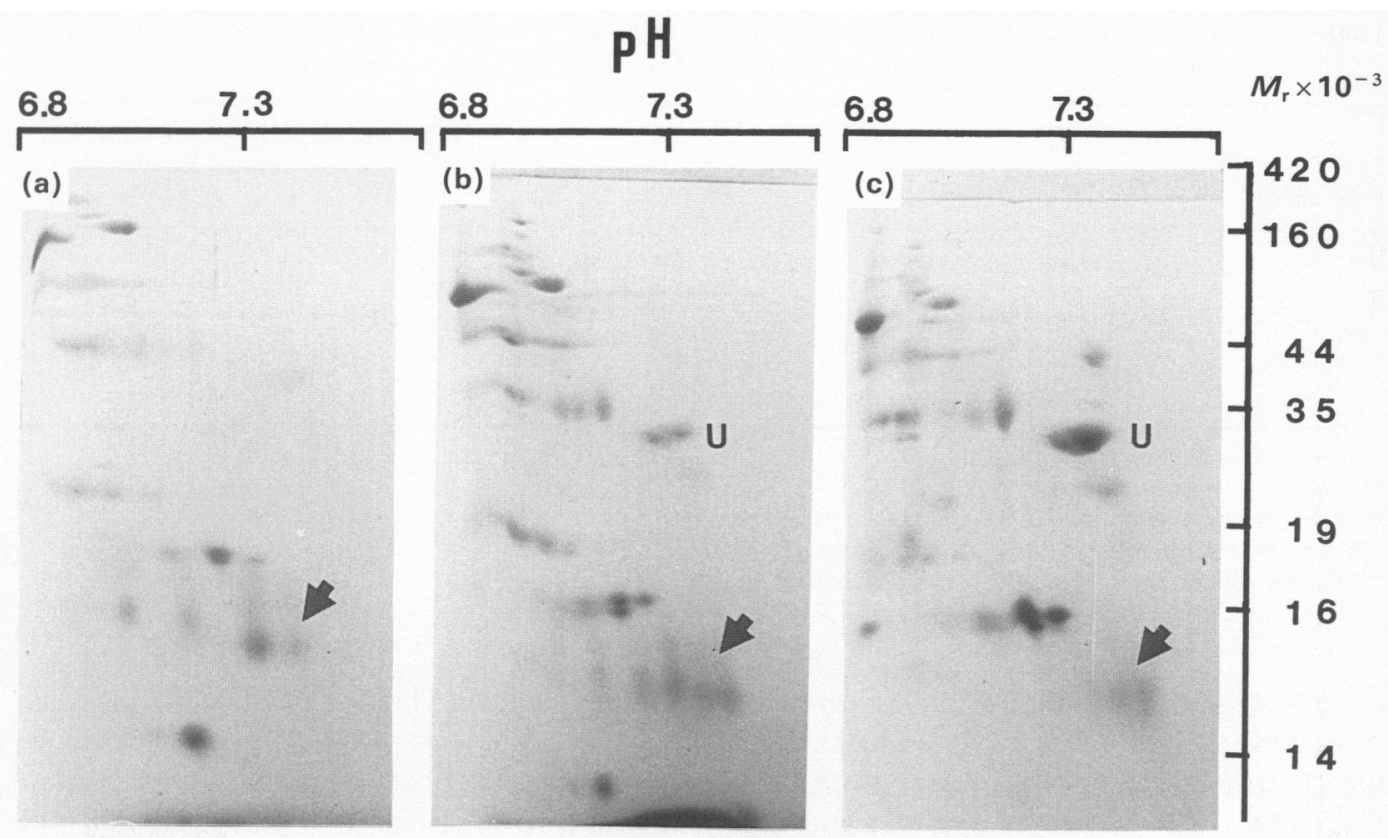

Fig. 3. Two-dimensional polyacrylamide gel electrophoresis of basic proteins in uterine flushings obtained from vehicle and oestradiol benzoate treated gilts. $U=$ uteroferrin; arrow = plasmin isoinhibitors. (a) Day 10 gilt, uterine flushing $12 \mathrm{~h}$ after oestradiol benzoate administration. (b) Day 12 gilt, uterine flushing $12 \mathrm{~h}$ after vehicle administration. (c) Day 12 gilt, uterine flushing $12 \mathrm{~h}$ after oestradiol benzoate administration.

by the letter $U$ and two other nonserum proteins $\left(M_{\mathrm{r}} \cong 50000-60000 ; \mathrm{pH} \mathrm{7 \cdot 2)}\right.$ located above uteroferrin appear after Day 11.5 (Fig. 3b), but were undetectable on Day 10 in vehicle- and oestradiol-treated gilts (Fig. 3a). Although these polypeptides are present in flushings from all gilts on Days 11.5 and 14, oestradiol benzoate treatment appeared to intensify their presence on Day $11 \cdot 5$ (Fig. 3c). Another complex of low molecular weight $\left(M_{\mathrm{r}} \cong 14500\right)$ polypeptides which have been identified as a family of plasmin isoinhibitors (Fazleabas et al. 1983), was also intensified after oestradiol benzoate treatment on Day 11.5.

\section{Experiment 4}

As shown in Table 3, treatment by day interactions were detected for calcium $(P<0.08)$, and acid phosphatase activity $(P<0.01)$. Acid phosphatase specific activity was affected by treatment

Fig. 2. Two-dimensional polyacrylamide gel electrophoresis of acidic proteins present in uterine flushings from vehicle- and oestradiol benzoate-treated gilts. In each case, $2 \mathrm{mg}$ dialysed protein was lyophilized, dissolved in $1 \mathrm{ml}$ of an alkaline urea buffer (see text) after which $300 \mu \mathrm{l}$ were loaded on the first dimension gel. $\mathrm{A}=$ serum albumin; open arrowhead $=$ two progesterone induced non-serum proteins. (a) Day 10 gilt, uterine flushing $12 \mathrm{~h}$ after oestradiol benzoate administration. (b) Day 12 gilt, uterine flushing $12 \mathrm{~h}$ after vehicle treatment. (c) Day 14.5 gilt uterine flushing $12 \mathrm{~h}$ after oestradiol benzoate administration. (d) Day 12 uterine flushing from a gilt treated with oestradiol benzoate on Day 9.5. Note the appearance of two proteins (solid arrowheads) which were not present previously in other treatment groups. 
Table 3. Means for total calcium, protein and acid phosphatase activity in uterine flushings of gilts treated with oestradiol benzoate and vehicle on Day $9 \cdot 5$ of the oestrous cycle (Exp. 4)

\begin{tabular}{lccccc}
\hline Treatment & Day & $\begin{array}{c}\text { Calcium } \\
(\mathrm{mg})^{*}\end{array}$ & $\begin{array}{c}\text { Protein } \\
(\mathrm{mg})\end{array}$ & $\begin{array}{c}\text { Acid phosphatase } \\
\text { activity** } \\
\left(\mu \mathrm{mol} \mathbf{P}_{\mathrm{i}} / \mathrm{min}\right)\end{array}$ & $\begin{array}{c}\text { Specific activity } \dagger \\
\left(\mu \mathrm{mol} \mathbf{P}_{\mathrm{i}} / \mathrm{min} / \mathrm{ng}\right. \\
\text { protein })\end{array}$ \\
\hline Vehicle & 11 & $0 \cdot 16$ & $33 \cdot 3^{\mathrm{a}}$ & $9 \cdot 1$ & $0 \cdot 30^{\mathrm{c}}$ \\
& 12 & $0 \cdot 28$ & $35 \cdot 1^{\mathrm{a}}$ & $20 \cdot 0$ & $1 \cdot 04^{\mathrm{d}}$ \\
Oestradiol & 11 & $0 \cdot 47$ & $36 \cdot 9^{\mathrm{a}}$ & $27 \cdot 3$ & $1 \cdot 44^{\mathrm{d}}$ \\
benzoate & 12 & $0 \cdot 14$ & $64 \cdot 9^{\mathrm{b}}$ & $141 \cdot 7$ & $2 \cdot 31^{\mathrm{e}}$ \\
& s.e.m. & $\pm 0 \cdot 14$ & $\pm 15 \cdot 8$ & $\pm 10 \cdot 5$ & $\pm 0 \cdot 29$ \\
\hline
\end{tabular}

*Treatment $x$ day interaction $(P<0.08)$.

**Treatment $x$ day interaction $(P<0.01)$.

$¥$ Treatment effect $(P<0.01)$; Day effect $(P<0.02)$.

a.bValues with different superscripts are different $(P<0 \cdot 10)$.

${ }^{\mathrm{c}, \mathrm{d}, \mathrm{e}}$ Values with different superscripts are different $(P<0.05)$.

$(P<0.01)$ and day $(P<0.02)$. Oestradiol benzoate treatment on Day 9.5 of the oestrous cycle stimulated an increase in uterine calcium on Day 11 followed by a decline on Day 12, whereas in vehicle-treated gilts levels increased from Days 11 to 12 . Acid phosphatase activity increased from Days 11 to 12 in oestradiol- and vehicle-treated gilts with activity in Day-12 flushings being 7-fold greater in gilts treated with oestradiol benzoate compared with controls $(P<0.01)$. Protein content in uterine flushings was similar for oestradiol- and vehicle-treated gilts on Day 11, but protein content was about 2 -fold greater $(P<0 \cdot 10)$ in oestradiol benzoate-treated gilts on Day 12 in contrast to only a slight change on Day 12 in vehicle-treated gilts.

Two-dimensional gel electrophoresis of uterine flushings indicated that oestradiol treatment on Day 9.5 visually enhanced the appearance of uteroferrin and the two other non-serum proteins on Day 12, as was also found in Exp. 3. The low molecular weight plasmin inhibitor polypeptides were also intensified by oestrogen treatment.

The two low molecular weight $\left(M_{\mathrm{r}} \cong 18000\right)$ acidic polypeptides described in Exp. 3 were present in the uterine flushings of vehicle- and oestradiol-treated gilts on Days 11 and 12. However, oestrogen administration on Day 9.5 apparently modified the staining intensity of these two polypeptides compared with that in vehicle-treated gilts (Fig. 2d). The administration of oestrogen on Day 9.5 appeared to enhance the staining intensity of these two polypeptides so that their visual appearance was even greater than that seen on Day 14 (Fig. 2c) in Exp. 3. Two very acidic (pH 5.4) polypeptides $\left(M_{\mathrm{r}} \cong 40000\right.$ and 30000 ) appeared in flushings from Day $9 \cdot 5$ oestradiol-treated gilts on Day 12 , but were absent in vehicle-treated gilts. These acidic polypeptides were not observed in oestradiol- or vehicle-treated gilts on any of the days in Exp. 3. These observations indicate that oestrogen treatment before Day 11 alters quantitative and qualitative secretion of uterine proteins released on Days 11-12.

\section{Discussion}

The present results, which are in agreement with those of Kidder et al. (1955), indicate that, in the gilt, a single injection of $5 \mathrm{mg}$ oestradiol benzoate between Days 9.5 and 15.5 of the oestrous cycle can lengthen the interoestrous interval to about 28 days. Utilizing the ability of oestrogen to prolong the interoestrous interval indicated that cycle lengths could be extended with oestrogen administration by at least the 9 th day of the cycle with responsiveness to the steroid declining after Day 14. 
The ability of oestradiol benzoate injections on Days 11 and 14-16 to produce a similar effect on extending the interoestrous interval, as reported by Frank et al. (1977), suggests that extension of the cycle length beyond 30 days in the gilt may require two phases of oestrogen stimulation. It appears that an initial oestrogen stimulation is required on Day 11 followed by a secondary sustained increase in oestrogen after Day 14.

Several lines of evidence support the proposed two phases for oestrogen induction of extended luteal maintenance. First, our results indicate that oestradiol treatment on Day 11 or Day 14-16 alone failed to extend the oestrous cycle length beyond 30 days, indicating that treatment on Days 11 and 14-16 was necessary for consistent luteal maintenance. Failure of oestradiol treatment on Days 11 and 14 as well as on Days 11 and 15 to extend the interoestrous interval beyond 30 days suggests that a sustained and intensified oestrogen stimulation is required during the second phase of administration. A single pharmacological dose $(5 \mathrm{mg})$ of oestradiol benzoate has been shown to elevate plasma oestrogen concentration for several days after treatment (Geisert et al., 1982c). However, as previously noted, this treatment did not result in extended luteal maintenance beyond 30 days. These results indicate that a prolonged exposure to high concentrations of oestrogen is necessary after Day 14 rather than just a persistent level of oestrogen which is consistent with the results of Saunders et al. (1983). Although the oestrogen treatments given in the present study are pharmacological, physiologically a similar change in blastocyst oestrogen secretion has been observed during pregnancy (Robertson et al., 1978; Bazer et al., 1982; Stone \& Seamark, 1985). The secondary sustained increase in blastocyst oestrogen secretion also appears to be involved with continued CL maintenance since flushing embryos from one uterine horn before Day 18 is not as effective in allowing maintenance of a unilateral pregnancy as flushing embryos on or after Day 18 (Dhindsa \& Dziuk, 1968).

The mechanism by which the two phases of oestrogen stimulation act together to prevent luteal regression after Day 22 and extend CL function beyond 30 days is presently not understood. The initial oestrogen stimulation on Day 11 stimulates the release of calcium and protein into the uterine lumen (Geisert et al., 1982c; present study), similar to that which occurs upon blastocyst oestrogen release (Geisert et al., 1982b). Although the interoestrous interval is extended by oestradiol benzoate treatment on Day 9.5, the results in Exp. 4 suggest that this response may have been stimulated by a residual effect as a consequence of the pharmacological levels of oestrogen still present on Day 11. It appears that the uterine endometrial secretion of calcium and protein is not responsive to oestrogen until after the 10th day of the oestrous cycle (Exp. 3), which would be in agreement with the normal synchrony of development and blastocyst oestrogen release (Geisert $e t$ al., 1982b). Lack of oestradiol stimulated release of uteroferrin and an increase in acid phosphatase activity in uterine flushings before Day 10 would indicate that secretory development was not completed. This is consistent with the lack of positive immunological staining for uteroferrin in the glandular epithelium until after Day 10 of the oestrous cycle (Renegar, 1982).

Identification of the two acidic (pH 5.4) polypeptides in Day 12 uterine flushings after oestrogen treatment on Day 9.5 is of interest. Pope \& First (1985) indicated that gilts administered oestrogen on Day 9 and 10 failed to maintain pregnancy to Day 30. At present, biological significance of the acidic polypeptides is unknown. In view of our results and those of Pope \& First (1985) additional studies are needed to ascertain the possible role of these polypeptides in conceptus development and survival.

Further studies are needed to clarify the possible involvement of the two oestrogen phases in PGF movement (Bazer \& Thatcher, 1977), synthesis (Guthrie \& Rexroad, 1981) and direct effects on CL function (Kraeling et al., 1975).

Journal Article No. 4997 of Agricultural Experiment Station, Oklahoma State University, Stillwater. We thank Dr K. T. Kirton (The Upjohn Company, Kalamazoo, Michigan) for the PGF antiserum; R. J. Rasby for surgical and technical assistance; and K. Frank for secretarial assistance. 


\section{References}

Alexander, R.L. (1971) Evaluations of an automatic calcium titrator. Clin. Chem. 17, 1171-1175.

Barr, A.J., Goodnight, J.H., Sall, J.P., Blair, W.H. \& Chilko, D.M. (1979) SAS User's Guide. SAS Institute Inc., Raleigh, N.C.

Basha, S.M.M., Bazer, F.W. \& Roberts, R.M. (1979) The secretion of a uterine specific, purple, phosphatase by cultured explants of porcine endometrium, depending upon the state of pregnancy of the donor animal. Biol. Reprod. 20, 431-441

Basha, S.M., Bazer, F.W., Geisert, R.D. \& Roberts, R.M. (1980) Progesterone-induced uterine secretions in pigs. Recovery from pseudopregnant and unilaterally pregnant gilts. J. Anim. Sci. 50, 113-123.

Bazer, F.W. \& Thatcher, W.W. (1977) Theory of maternal recognition of pregnancy in swine based on oestrogen controlled endocrine versus exocrine secretion of prostaglandin $F 2 \alpha$ by the uterine endometrium. Prostaglandins 14, 397-401.

Bazer, F.W., Geisert, R.D., Thatcher, W.W. \& Roberts, R.M. (1982) The establishment and maintenance of pregnancy. In Control of Pig Reproduction, pp. 227-252. Eds D. J. A. Cole \& G. R. Foxcroft. Butterworth Scientific, London.

Bazer, F.W., Marengo, S.R., Geisert, R.D. \& Thatcher, W.W. (1984) Exocrine versus endocrine secretion of prostaglandin $\mathrm{F}$ in the control of pregnancy in swine. Anim. Reprod. Sci. 7, 115-132.

Cornette, J.C., Kirton, K.T., Barr, K.L. \& Forbes, A.D. (1972) Radioimmunoassay of prostaglandins. $J$. Reprod. Med. 9, 355-360.

Dhindsa, D.S. \& Dziuk, P.J. (1968) Effect on pregnancy in the pig after killing fetuses or embryos in one uterine horn in early gestation. J. Anim. Sci. 27, 122-126.

Fazleabas, A.T., Geisert, R.D., Bazer, F.W. \& Roberts, R.M. (1983) Relationships between release of plasminogen activator and estrogen by blastocysts and secretion of plasmin inhibitor by uterine endometrium in the pregnant pig. Biol. Reprod. 29, 225-228.

Frank, M., Bazer, F.W., Thatcher, W.W. \& Wilcox, C.J. (1977) A study of prostaglandin F2 $\alpha$ as a luteolysin in swine: III. Effects of estradiol valerate on prostaglandin F, progestins, estrone and estradiol concentrations in utero-ovarian vein of nonpregnant gilts. Prostaglandins 14, 1183-1196.

Gadsby, J.E., Heap, R.P. \& Burton, R.D. (1980) Oestrogen production by blastocyst and early embryonic tissues of various species. J. Reprod. Fert. 60, 409-417.

Gardner, M.L., First, N.L. \& Casida, L.E. (1963) Effect of exogenous estrogen on corpus luteum maintenance in gilts. J. Anim. Sci. 22, 132-134.

Geisert, R.D., Brookbank, J.W., Roberts, R.M. \& Bazer, F.W. (1982a) Establishment of pregnancy in the pig: II. Cellular remodelling of the porcine blastocysts during elongation on Day 12 of pregnancy. Biol. Reprod. 26, $941-955$.
Geisert, R.D., Renegar, R.H., Thatcher, W.W., Roberts, R.M. \& Bazer, F.W. (1982b) Establishment of pregnancy in the pig. I. Interrelationships between preimplantation development of the pig blastocyst and uterine endometrial secretions. Biol. Reprod. 27, 925-939.

Geisert, R.D., Renegar, R.H., Thatcher, W.W., Roberts, R.M. \& Bazer, F.W. (1982c) Establishment of pregnancy in the pig. II. Endometrial secretory response to estradiol valerate administered on day 11 of the estrous cycle. Biol. Reprod. 27, 957-965.

Geisert, R.D., Rasby, R.J., Minton, J.E. \& Wettemann, R.P. (1986) Role of prostaglandins in preimplantation development of porcine blastocysts. Prostaglandins 31, 191-204.

Gill, J.L. \& Hafs, H.D. (1971) Analysis of repeated measurements of animals. J. Anim. Sci. 33, 331-336.

Guthrie, H.D. \& Rexroad, C.E.J. (1981) Endometrial prostaglandin $F$ release in vitro and plasma 13 , 14-dihydro-15-keto-prostaglandin F2 $\alpha$ in pigs with luteolysis blocked by pregnancy, estradiol benzoate or human chorionic gonadotrophin. J. Anim. Sci. 52, 330-339.

Hallford, D.M., Wettemann, R.P., Turman, E.J. \& Omtvedt, I.T. (1975) Luteal function in gilts after prostaglandin F2a. J. Anim. Sci. 41, 1706 1710.

Kidder, H.E., Casida, L.E. \& Grummer, R.H. (1955) Some effects of estrogen injections on the estrual cycle of gilts. J. Anim. Sci. 14, 470-474.

Kraeling, R.R., Rampacek, G.B. \& Ball, G.D. (1975) Estradiol inhibition of PGF $2 \alpha$ luteolysis in the pig. $J$. Anim. Sci. 41, 363, Abstr.

Lowry, O.H., Rosebrough, N.J., Farr, A.L. \& Randall, R.J. (1951) Protein measurement with the folin phenol reagent. J. biol. Chem. 193, 265-275.

Perry, J.S., Heap, R.B. \& Amoroso, E.C. (1973) Steroid hormone production by pig blastocysts. Nature, Lond. 245, 45-47.

Pope, W.F. \& First, N.L. (1985) Factors affecting the survival of pig embryos. Theriogenology 23, 91-105.

Renegar, R.H (1982) An ultrastructural and cytochemical investigation of endometrium from pregnant and nonpregnant gilts. Ph.D. dissertation, University of Florida, Gainesville.

Robertson, H.A., King, G.J. \& Dyck, G.W. (1978) The appearance of oestrone sulphate in the peripheral plasma of the pig early in pregnancy. J. Reprod. Fert. 52, 337-338.

Saunders, M.J., Edgerton, L.A., Kagan, J.M., Stahly, T.S. \& Cromwell, G.L. (1983) Comparison of intrauterine and subcutaneous sites of estrogen injection for luteal maintenance in swine. J. Anim. Sci. 57, 146-149.

Stone, B.A. \& Seamark, R.F. (1985) Steroid hormones in uterine washings and in plasma of gilts between Days 9 and 15 after oestrus and between Days 9 and 15 after coitus. J. Reprod. Fert. 75, 209-221.

Received 8 May 1986 